\title{
Does the Fit of Managerial Ability with Firm Strategy Matters on Firm Performance*
}

\author{
Teng Yuan CHENG**, Yue-Qi LI***, Yu-En LIN****, Hsiang-Hsuan CHIH*****
}

Received: November 8, 2019 Revised: February 24, 2020 Accepted: March 1, 2020.

\begin{abstract}
The study aims to answer why the previous studies find the positive or insignificant effect of the CEO's abilities on firm performance. Using 34,285 CEO-firm-year panel data from the U.S. publicly traded firms drawn from the BoardEx and EXECUXOMP database during from 1992 to 2014, the results show that the fit of the CEO's generality or specialist ability with firm strategy matters on firm performance and risk. This study computes a discrete STRATEGY composite measure to construct firm strategy types, such as Prospect or Defend and use CEOs' résumés to construct an index of general skills that are transferable across firms and industries. The results find that generalist CEOs are more suitable for prospectors than specialist CEOs. Firm performance is much better when specialist CEOs work for Defenders. Although the firm performance is better too for the generalist CEOs who fit for the Prospect strategy, the firm's risk is up too. The result suggests that firms need to consider their chosen business strategy to recruit and select CEOs Our findings provide direct evidence that the match between CEO's ability and the firm's strategy is crucial to firm performance and risk.
\end{abstract}

Keywords : Generalist, General Ability Index, Specialist, Strategy, Performance

JEL Classification Code : D21 G34 J24

\section{Introduction and Literature Review}

Although general managerial ability and strategy are important for resource allocation (Demerjian, Lev, \& McVay, 2012; Choi, Han, Jung, \& Kang, 2015), we still

*We would like to thank the financial support from Jilin Social Science Fund (Grant No. 2019B49) and from the scientific research planning project of Jilin Provincial Department of Education (Grant No. JJKH20201146SK).

${ }^{* *}$ First Author. Professor, School of Finance, Nanjing Audit University, P.R. China, Email:tybrian@gmail.com

${ }^{* * *}$ Graduate student, Business School, Nanjing University, P.R. China, Email: liyq@smail.nju.edu.cn

${ }^{* * * *}$ Corresponding Author. Associate Professor, Center for Quantitative Economics, Jilin University, China [Postal Address: No.2699 Qianjin Street, Changchun City, Jilin Province, 130012, P.R. China] Tel: (+86) 173-9006-9319,

E-mail: sas@jlu.edu.cn

*****Professor, Department of Finance, National Dong Hwa University, Taiwan, R.O.C. Email: hhchih@gms.ndhu.edu.tw

(c) Copyright: The Author(s)

This is an Open Access article distributed under the terms of the Creative Commons Attribution Non-Commercial License (http://Creativecommons.org/licenses/by-nc/4.0/) which permits unrestricted noncommercial use, distribution, and reproduction in any medium, provided the original work is properly cited. know very little about its nature. It is well-known that organizational capital is a highly valuable asset of the firm, at the nucleus of which resides the firm's chief executive officer (CEO) (Mishra, 2014). The general managerial skills, which are transferable across companies or even industries, have relatively become more important than firm-specific knowledge in the case of CEO function (Murphy \& Zabojnik, 2004). Moreover, Miles and Snow's strategic typology consists of four strategic types as prospectors, analyzers, defenders, and reactors. The typology suggests that three viable business strategies (prospectors, defenders, and analyzers) may exist simultaneously within industries. Prospectors are innovative companies seeking to identify and exploit new products and market opportunities (Miles \& Snow, 1978, 2003). They prefer uncertainty, undergo constant change, and tend to sell unique products that cannot be substituted. Defenders are companies focused on efficiency in the production and distribution of goods and services (Miles \& Snow, 1978, 2003). They follow a cost leadership strategy, minimize their exposure to risk and uncertainty, and strive to maintain organizational and operational stability. Analyzers have attributes of both Defenders and 
Prospectors. Consistent with prior research in both management and accounting (e.g., Hambrick, 1981, 1983; Simons, 1987; Ittner, Larcker, \& Rajan, 1997), we focus on the two distinct strategies at the ends of continuum, prospectors and defenders. We include Analyzers in our analyses only as a benchmark to compare with Defenders and Prospectors.

In addition to Miles and Snow $(1978,2003)$, some of the more well-known types include Porter (1980) who describes business strategy in terms of cost leadership and product differentiation; March (1991) who describes business strategy in terms of exploration and exploitation; and Treacy and Wiersema (1995) who describes business strategy in terms of operational excellence, product leadership, and customer intimacy. While the labels for the strategic types differ across the various typologies, one common feature among all the proposed strategy classifications is that each clearly defines firms at the ends of a strategic continuum (Dent, 1990; Langfield-Smith, 1997; Seifzadeh, 2011). We select the Miles and Snow classification because this typology is one of the most popular and well-cited theories of strategic types.

Considerable early empirical research argues that business strategy is an important determinant of firm performance (e.g., Govindarajan \& Shank, 1993; Ramaswamy \& Thomas, 1996; Waterhouse \& Svendsen, 1998). Recent research examines how strategy can influence firm performance or risk (Cha, Hwang, \& Kim, 2019). However, some academics find that business strategy is not a one-dimensional impact on firm performance. If the business strategy does not fit to the compensation structure, there is a negative impact on performance (Chen \& Jermias, 2014; Sheikh, Bhutta, \& Sultan, 2019).

To begin to measure CEO's general managerial skills is by Custódio, Ferreira, and Matos (2013). They define the general managerial skills of CEOs as those skills acquired through a lifetime of work experience, particularly work experience gained in some functional areas, in firms and industries and from past CEO positions at other firms and conglomerates. Opposite to the general managerial skills, specialist skills are not readily transferable across firms or industries but may be highly valuable within a particular firm or industry. General managerial skills are not firmspecific managerial capital and are transferable across firms or industries. They may be suitable for conglomerate firms (Xuan, 2009) and the firms facing product market changes due to industry deregulation (Hubbard \& Palia, 1995), foreign competition (Cunat \& Guadalupe, 2009), and changes in technology and management practices (Garicano \& Rossi-Hansberg, 2006). This study aims to examine whether the interaction between firm strategy and generalist/specialist CEOs matters for firm performance and risk or whether generalist/specialist CEOs influence firm performance and risk solely. In addition, we test whether the fit between firm strategy and general (or specialist) managerial skills matter for firm performance and risk.

Following the prior studies, our measure of general managerial skills consists of five aspects of a CEO's professional career: (1) The number of positions held by a CEO; (2) a CEO's employment at a number of different firms; (3) a CEO's employment in a number of different industries; (4) whether the CEO held a CEO position at a different company; (5) whether the CEO worked for a conglomerate (Custódio et al., 2013; Mishra, 2014; Brockman, Lee, \& Salas, 2016; Gounopoulos \& Pham, 2018; Custódio, Ferreira, \& Matos, 2019). The index summarizes information on a CEO's general skills and allows us to classify a CEO as a generalist or a specialist.

Despite the widely-held premise that general managerial ability is an important mechanism for firm performance, previous empirical studies report a strong or insignificant relationship between general managerial ability and firm performance (e.g., Rosen, 1981; Gabaix \& Landier, 2008; Mark, Morten, \& Steven, 2012; Leverty \& Grace, 2012; Custódio et al., 2013; Mishra, 2014; Choi, Han, Jung, \& Kang, 2015; Andreou, Ehrlich, Karasamani, \& Louca, 2017; Gounopoulos \& Pham, 2018; Nguyen, Mai, \& Huynh, 2019). These studies indicate that subsequent performance is positively related to general ability and execution skills (Mark et al., 2012), and generalist CEOs may positively affect firm performance (Mishra, 2014). A recent study by Mark et al. (2012) found that for venture capital firms, some personalities, such as teamwork and interpersonalteam factors, are negatively related to performance. However, evidence also exists, suggesting that there is a statistically insignificant relation between firm performance and the index of the general managerial ability of the CEO (Custódio et al., 2013).

Managers with superior ability are receptive to risktaking, whereas managers with inferior ability refrain from risk-taking (Yung \& Chen, 2018). Generalist CEOs have less incentive to reduce risk compared to specialist CEOs (May, 1995). Graham, Harvey, and Puri (2010) provide additional evidence that CEO behavior is related to measures of overconfidence, optimism, and risk aversion. Mishra (2014) argued that generalist CEOs might lead to greater agency problems, feature different risk-taking incentives and be more costly to retain in times of need. A firm's CEO ability heterogeneity and the board's recruitment ability both significantly and negatively affect its credit risk (Chen, Kim, \& Yao, 2017). Thus, we inquire whether there are any risk implications for firms having or not having generalist CEOs. 
The objective of this study is to investigate the impact of business strategy on US public firms with generalist CEOs or specialist CEOs. Furthermore, we examine the impact of the fit between general managerial ability and strategy on firm performance and risk. Using Miles and Snow's typology to classify a firm's business strategy, we predict and find that fit between general managerial ability and business strategy has a positive effect on firm performance and risk.

This study contributes to the existing literature on the general managerial ability by recognizing that a fit of a firm's strategy with general managerial ability positively affects performance and negatively affects risk. First, our results contribute to the stream of research that helps explain the association between managerial ability and firm performance (e.g., Mark et al., 2012; Leverty \& Grace, 2012; Custódio et al., 2013; Mishra, 2014; Choi et al., 2015; Andreou et al., 2017; Gounopoulos \& Pham, 2018). We show that after controlling business strategy, the CEO's general ability is an important feature that creates superior performance.

Second, our results also have a practical implication on the recruitment and selection of CEOs, suggesting that the companies need to align CEO managerial ability with their strategy to affect performance positively. Each of the strategies also requires different types of employees with specific skills. The human resource manager must ensure that the organization is staffed with people who have the necessary knowledge, skill, and ability to perform their job when implementing the strategy. Thus, when companies recruit or select CEOs, they need to consider their own strategies. Additionally, the change in strategy also requires different types of skills, employees, and behaviors.

Third, prospectors focus on innovation and change with a more flexible organization structure. Defenders focus on efficiency with a stable organizational structure. The key dimension of the strategy typology is the organization's rate of change regarding its products and markets (Hambrick, 1983). That means the strategic choice is a certain aspect of the organization's situation (Mintzberg, 1979).

Finally, it extends the literature that examines managerial ability (e.g., Mark et al., 2012; Leverty \& Grace, 2012; Custódio et al., 2013; Mishra, 2014; Choi et al., 2015; Andreou et al., 2017; Gounopoulos \& Pham, 2018) and strategy (e.g., Bentley, Sharp, \& Omer, 2013; Higgins, Omer, \& Phillips, 2015; Habib \& Hasan, 2016; Liu \& Zhang, 2017). They argue that firm performance and the index of the general managerial ability of the CEO are insignificantly related. Our study provides evidence to extend this finding by showing that taking into consideration the fit between managerial ability and firm strategy may help explain the previous insignificant or opposite relationship between general managerial ability and firm performance. Additionally, our study extends the findings of Higgins et al. (2015), who take a measurement perspective of strategy and show that a firm's business strategy is associated with its level of tax avoidance. We show that after controlling for managerial ability, business strategy is an important feature that creates some risk.

The remainder of this study proceeds as follows. The next section describes the sample selection, variable construction, and data description. Section 3 depicts the results of statistical tests. Section 4 presents the results of robustness tests. The final section discusses this study's major findings and limitations, as well as its implications for future research in this area.

\section{Data and Methodology}

\subsection{Sample}

Our initial sample consists of a panel of 34,285 CEOfirm-years during the period from 1992 to 2014 drawn from the BoardEx and EXECUXOMP database. We match the executives in BoardEx with EXECUCOMP who are identified as CEOs in a specific year with data in the Center for Research in Security Prices (CRSP) and COMPUSTAT database. Following Higgins et al. (2015), we delete firmyear observations associated with firms in financial services and regulated industries (two-digit SIC codes 49, 60-69). We express the CEO's age and tenure variables by taking the natural logarithm. We also winsorize all continuous variables at the $1^{\text {st }}$ and $99^{\text {th }}$ percentile to exclude the influence of outlier observations. Finally, our sample consists of 16,822 firm-year observations for ROE during the period 1992 to 2014 and 7,187 firm-year observations for stdROE during the period 1992 to 2014.

\subsection{General Managerial Ability Composite Measure}

To assign CEOs a managerial ability index, we compute a discrete General Ability Index (GAI), which captures the skills of the CEO. Such that the GAI is able to transferrable across firms and industries, instead of being firm-specific. This measure is based on variables from prior literature (Custódio et al., 2013) that reflect the CEO's unobserved construct. Following Custódio et al. (2013), we employ the following variables to construct GAI: (a) the number of positions, (b) the number of firms, (c) the number of industries, (d) CEO experience dummy, and (e) conglomerate experience dummy. Each of the five measures from EXECUCOMP aims to capture different elements of a CEO's ability. 
The number of positions is measured by the number of different functional positions that a CEO is responsible for during his career. CEO with more diversified positions is more likely to be exposed to different organizational areas such as production, finance, human resources, sales, and marketing. The number of firms is measured by the number of firms where a CEO worked. Because a CEO who worked for multiple firms may acquire more generic skills as opposed to firm-specific skills. The number of industries is measured by the number of industries at the four-digit SIC level where a CEO worked. Because a CEO who worked in different industries has been exposed to different business environments. CEO Experience Dummy would equal one if a CEO held a CEO position at another firm because a CEO position requires a set of generic skills to deal with different organizational areas and the many external entities such as stakeholders, media and capital markets. Conglomerate experience dummy equals one if a CEO worked for a multidivision firm because a CEO who worked for a conglomerate has been exposed to a more complex organization and likely has more attractive outside options.

Consistent with Custódio et al. (2013), we employ the first principal component of these five variables, which has an eigenvalue of 2.984 and positive loadings for all five variables. Following Custódio et al. (2013) and Mishra (2014), we classify CEOs with an index higher than the yearly median as generalists and CEOs with an index lower than the yearly median as specialists.

\subsection{Business Strategy Composite Measure}

We aim to examine whether firms that follow different strategies and who have different performance and risk from other similar firms that feature generalist CEOs vs. specialist CEOs. Owing to this purpose, we follow the methodology by Bentley et al. (2013) and Higgins et al. (2015) and borrow the discrete STRATEGY composite measure, which proxies the organizational business strategy. Higher STRATEGY scores represent companies with prospector strategies and lower scores represent companies with defender strategies. Similar to Bentley (2013), we use the following characteristics for the STRATEGY composite measure: (a) the ratio of research and development to sales, (b) the ratio of employees to sales, (c) a historical growth measure(one-year percentage change in total sales), (d) the ratio of marketing (SG\&A) to sales, (e) employee fluctuations(standard deviation of total employees) and (f) capital intensity (net PPE scaled by total assets), respectively.

Consistent with Ittner et al. (1997), Bentley et al. (2013) and Higgins et al. (2015), all variables are computed using a rolling average of the respective yearly ratios over the prior five years. Each of the six individual variables is ranked by forming quintiles within each two-digit SIC industry-year. Within each industry-year, observations with variables in the highest quintile are given a score of 5 , in the second-highest quintile are given a score of 4 and so on. Those in the lowest quintile are given a score of 1 . Then for each company-year, we sum the scores across the six variables such that the maximum STRATEGY score a company could receive is 30 , and the minimum score a company could receive is 6. Higher STRATEGY scores represent Prospector companies, while lower STRATEGY scores represent Defender companies.

\subsection{Measurement of Performance and Risk}

The dependent variable in this paper is firm performance or risk. We use ROE from COMPUSTAT and multiply it by 100 as the firm performance. The mean (median) of ROE in Table 2 is 27.372 (27.575). The measure of the risk is the volatility of the firm's return on equity, defined as the ratio of net income to book equity. We obtain ROE in every quarter and multiplied it by 100 . Then we calculate the quarterly standard deviation of ROE in the next 12 quarters. We use the quarterly standard deviation of ROE in the fourth quarter as the risk. The mean (median) of the standard deviation of ROE is 6.884 (21.942). The volatility of returns is a standard proxy for risk in the financial economics literature. This variable captures the riskiness of investment decisions. Further, earlier work establishes that the volatility of firm-level operating profits has a positive impact on long-term economic growth. We focus on the volatility of accounting returns (as opposed to stock market returns) as the vast majority of firms in our sample are privately held.

\subsection{Control Variables}

Following Bentley et al. (2013), Custódio et al. (2013), Higgins et al. (2015) and Mukherjee and Nguyen (2018), we include several CEO's and firm's characteristics that are potentially correlated with general managerial ability, strategy and firm performance and risk as control variables. We describe these variables below. Age is the natural logarithm of the CEO age. The mean (median) of the natural logarithm of the CEO age is 4.012(0.123). Tenure is the natural logarithm of the number of years as CEO in the current position. The mean (median) of the natural logarithm of tenure is $1.672(0.932)$. MBA is a dummy variable that takes a value one if the $\mathrm{CEO}$ has a master of business administration (MBA) degree, and zero otherwise. The mean (median) of MBA is $0.423(0.494)$. Gender is a dummy variable that takes a value one if the CEO is a male; 
otherwise, zero. The mean (median) of gender is 0.977 (0.149).

Cash is the cash and short-term investments divided by total assets. The mean (median) of cash is $0.147(0.157)$. CEO_CHG is a dummy variable that takes a value one if the firm changed CEO, and zero, otherwise. The mean (median) of CEO_CHG is 0.091 (0.287). BM is the book value of equity divided by the market value of equity. The mean (median) of BM is $0.449(0.274)$. SGR is the annual sales growth. The mean (median) of SGR is $0.107(0.196)$. Leverage is the financial leverage equal to total debt divided by total assets. The mean (median) of leverage is $0.205(0.151)$.

Table 1 provides the definitions of variables. Corporate accounting data come from the Center for Research in Security Prices (CRSP) and COMPUSTAT database available on the Wharton Research Data Services (WRDS) server. General managerial ability data come from BoardEx. CEO characteristic data come from the EXECUCOMP database. Sample firms are the U.S. publicly traded firms in the COMPUSTAT database from 1992 to 2014 with nonmissing data for all variables. Financial and regulated firms are excluded.

Table 1: Variable definitions

\begin{tabular}{|c|c|}
\hline Name & Definition \\
\hline ROE & Net income divided by book equity. \\
\hline stdROE & $\begin{array}{c}\text { Standard deviation of Return on Equity (ROE). } \\
\text { first factor of applying principal components analysis } \\
\text { Number of Positions, Number of Firms, Number of } \\
\text { Industries, CEO Experience Dummy, and Conglomerate } \\
\text { Experience Dummy. }\end{array}$ \\
\hline strategy & $\begin{array}{c}\text { Discrete score with values ranging from 6 to 30 where } \\
\text { high (middle) [low] values indicate Prospector } \\
\text { (Analyzer) [Defender] firms, respectively. }\end{array}$ \\
\hline age & Natural logarithm of the age of the CEO in years. \\
\hline tenure & $\begin{array}{c}\text { Natural logarithm of the number of years as the CEO in } \\
\text { the current position. }\end{array}$ \\
\hline MBA & $\begin{array}{c}\text { Dummy variable that takes a value one if the CEO has a } \\
\text { master of business administration (MBA) degree, and } \\
\text { zero otherwise. }\end{array}$ \\
\hline gender & $\begin{array}{c}\text { Dummy variable that takes a value 1 if the CEO is a } \\
\text { male, and 0, otherwise. }\end{array}$ \\
\hline cash & Cash and short-term investments divided by total assets. \\
\hline CEO_CHG & $\begin{array}{c}\text { Dummy variable that takes a value one if the firm } \\
\text { changed the CEO, and 0, otherwise. }\end{array}$ \\
\hline BM & $\begin{array}{c}\text { The book value of equity divided by the market value of } \\
\text { assets. }\end{array}$ \\
\hline leverage & $\begin{array}{c}\text { Financial leverage equal to total debt divided by total } \\
\text { and }\end{array}$ \\
\hline
\end{tabular}

\subsection{Empirical Model}

We employ the following regression models (1) and (3) to investigate the association between general managerial ability and firm performance and risk. In the models (2) and (4), we add GAI*strategy to test if specialists work for defenders and generalists work for prospectors.

$$
\begin{aligned}
& R O E_{i, t+1}=\alpha+\beta_{1} G A I_{i, t}+\beta_{2} \text { strategy }_{i, t}+\beta_{3} a g e_{i, t} \\
& +\beta_{4} \text { tenure }_{i, t}+\beta_{5} M B A_{i, t} \\
& +\beta_{6} \text { gender }_{i, t}+\beta_{7} \text { cas }_{i, t} \\
& +\beta_{8} C E O_{C H G_{i, t}}+\beta_{9} B M_{i, t}+\beta_{10} S G R_{i, t} \\
& +\beta_{11} \text { leverage }_{i, t}+\beta_{k} Y E A R \\
& +\beta_{j} \text { INDUSTRY }+\varepsilon_{i, t} \\
& \operatorname{ROE}_{i, t+1}=\alpha+\beta_{1} G A I_{i, t}+\lambda G A I_{i, t} * \text { strategy }_{i, t} \\
& +\beta_{2} \text { strategy }_{i, t}+\beta_{3} \text { age } e_{i, t} \\
& +\beta_{4} \text { tenure }_{i, t}+\beta_{5} M B A_{i, t}+\beta_{6} \text { gender }_{i, t} \\
& +\beta_{7} \text { cas } \square_{i, t}+\beta_{8} C_{E O} O_{-} C H G_{i, t}+\beta_{9} B M_{i, t} \\
& +\beta_{10} S G R_{i, t}+\beta_{11} \text { leverage }_{i, t}+\beta_{k} Y E A R \\
& +\beta_{j} \text { INDUSTRY }+\varepsilon_{i, t}
\end{aligned}
$$

We provide variable definitions in Table 1 . We discuss our expectations for the model coefficients below, based on Miles and Snow $(1978,2003)$ and the prior performance literature. We expect the coefficient for GAI*strategy to be positive if specialists work for defenders and generalists work for prospectors. We do not predict a sign for the coefficients on GAI based on the mixed results in prior research (e.g., Mark et al., 2012; Custódio et al., 2013; Mishra, 2014; Andreou et al., 2017; Gounopoulos \& Pham, 2018). Similar to prior research, we expect a negative coefficient on strategy (e.g., Govindarajan \& Shank, 1993; Ramaswamy \& Thomas, 1996; Waterhouse \& Svendsen, 1998).

$$
\begin{aligned}
\operatorname{std} R O E_{i, t}=\alpha+ & \beta_{1} G_{i, t}+\beta_{2} \text { strategy }_{i, t}+\beta_{3} \text { age }_{i, t} \\
& +\beta_{4} \text { tenure }_{i, t}+\beta_{5} \text { MBA }_{i, t} \\
& +\beta_{6} \text { gender }_{i, t}+\beta_{7} \text { cash }_{i, t} \\
& +\beta_{8} \text { CEO_CHG }_{i, t}+\beta_{9} B M_{i, t}+\beta_{10} S G R_{i, t} \\
& +\beta_{11} \text { leverage }_{i, t}+\beta_{k} Y E A R \\
& +\beta_{j} \text { INDUSTRY }+\varepsilon_{i, t}
\end{aligned}
$$

$$
\begin{aligned}
\operatorname{std} R O E_{i, t}=\alpha+ & \beta_{1} G_{i, t}+\lambda G A I_{i, t} * \text { strategy }_{i, t} \\
& +\beta_{2} \text { strategy }_{i, t}+\beta_{3} \text { age }_{i, t} \\
& +\beta_{4} \text { tenure }_{i, t}+\beta_{5} \text { MBA }_{i, t} \\
& +\beta_{6} \text { gender }_{i, t}+\beta_{7} \text { cash }_{i, t} \\
& +\beta_{8} \text { CEO }_{\text {CHG }_{i, t}}+\beta_{9} B M_{i, t}+\beta_{10} S_{G} R_{i, t} \\
& +\beta_{11} \text { leverage }_{i, t}+\beta_{k} Y E A R \\
& +\beta_{j} \text { INDUSTRY }+\varepsilon_{i, t}
\end{aligned}
$$


We provide variable definitions in Table 1 . We discuss our expectations for the model coefficients below, based on Miles and Snow $(1978,2003)$ and the prior risk literature. We expect the coefficient for GAI*strategy to be positive if specialists work for defenders and generalists work for prospectors. Based on prior research, we expect a negative sign for the coefficient on GAI (e.g., May, 1995; Mishra, 2014; Chen et al., 2017; Yung \& Chen, 2018). Similar to prior research, we expect a negative coefficient on strategy (e.g., Higgins et al., 2015).

\section{Empirical Results}

Table 2 shows descriptive statistics for ROE, stdROE, GAI, and strategy. Besides the CEO's ability in GAI, we measure some additional CEO characteristics: age, tenure, MBA, and gender. We also control the tests for firm characteristics: cash, CEO_CHG, BM, SGR, and leverage. All variables are winsorized at the 1st and 99th percentile values. This table presents the mean, standard deviation, Q1, median, Q3 for each variable. The sample consists of firms for which chief executive officer (CEO) profile data are available from COMPUSTAT and CRSP during the period from 1992 to 2014. All variables are winsorized at the 1st and 99 th percentile values.

Table 2: Descriptive statistics

\begin{tabular}{|c|c|c|c|c|c|}
\hline & MEAN & STD & Q1 & MEDIAN & Q3 \\
\hline ROE & 27.372 & 27.575 & 14.675 & 23.629 & 34.415 \\
\hline
\end{tabular}

\begin{tabular}{|c|c|c|c|c|c|}
\hline & MEAN & STD & Q1 & MEDIAN & Q3 \\
\hline stdROE & 6.884 & 21.942 & 1.188 & 1.984 & 3.688 \\
\hline GAI & 2.147 & 1.188 & 1.042 & 1.931 & 2.820 \\
\hline STRATEGY & 18.860 & 2.787 & 17.000 & 19.000 & 21.000 \\
\hline AGE & 4.012 & 0.123 & 3.932 & 4.025 & 4.094 \\
\hline TENURE & 1.672 & 0.932 & 1.099 & 1.778 & 2.327 \\
\hline MBA & 0.423 & 0.494 & 0.000 & 0.000 & 1.000 \\
\hline GENDER & 0.977 & 0.149 & 1.000 & 1.000 & 1.000 \\
\hline CASH & 0.147 & 0.157 & 0.030 & 0.089 & 0.214 \\
\hline CEO_CHG & 0.091 & 0.287 & 0.000 & 0.000 & 0.000 \\
\hline BM & 0.449 & 0.274 & 0.251 & 0.388 & 0.588 \\
\hline SGR & 0.107 & 0.196 & 0.015 & 0.083 & 0.170 \\
\hline LEVERAGE & 0.205 & 0.151 & 0.078 & 0.201 & 0.307 \\
\hline
\end{tabular}

Table 3 presents the correlation coefficients of the main variables Pearson correlations are presented in the lower left and Spearman correlations are in the upper right. The results indicate that both the Pearson and Spearman correlations are qualitatively similar, and therefore, we will discuss only the Pearson correlations with respect to the test variables. It shows that the correlation coefficient for GAI and ROE is not significant, which is by our expectation. Meanwhile, GAI and stdROE are significantly and positively correlated. Among the model variables, the correlations are consistent with prior literature, and there are no Pearson correlations greater than 0.50 . To further examine the relationship between these variables, we ran standard OLS regression analysis with them.

Table 3: Correlation coefficient

\begin{tabular}{|c|c|c|c|c|c|c|c|c|c|c|c|c|c|}
\hline & ROE & stdROE & GAI & STRATEGY & AGE & TENURE & MBA & GENDER & CASH & CEO_CHG & BM & SGR & LEVERAGE \\
\hline ROE & 1.000 & $0.034^{* * * *}$ & $0.048^{* * *}$ & $0.026^{* * *}$ & $0.108^{* * *}$ & $-0.023^{* *}$ & $0.150^{* * * *}$ & $0.019^{* * *}$ & $-0.187^{* * *}$ & $0.019^{* *}$ & $-0.512^{* * * *}$ & $0.088^{* * * *}$ & $0.233^{* * *}$ \\
\hline stdROE & $0.181^{* * *}$ & 1.000 & $0.060^{* * * *}$ & 0.014 & $-0.038^{* * * *}$ & 0.015 & $-0.072^{* * *}$ & $-0.062^{* * *}$ & $0.172^{* * *}$ & 0.007 & $-0.078^{* * * *}$ & -0.002 & $0.047^{* * *}$ \\
\hline GAI & $0.058^{* * *}$ & $0.061^{* * * *}$ & 1.000 & -0.003 & $0.089^{* * * *}$ & $0.054^{* * *}$ & $0.080^{* * *}$ & $-0.053^{* * *}$ & $-0.039^{* * * *}$ & $-0.075^{* * *}$ & 0.003 & $-0.086^{* * *}$ & $0.062^{* * *}$ \\
\hline STRATEGY & 0.014 & $0.018^{* * *}$ & -0.015 & 1.000 & -0.011 & $-0.020^{* *}$ & $0.103^{* * *}$ & 0.015 & $-0.086^{* * *}$ & 0.012 & $-0.032^{* * *}$ & 0.012 & $0.049^{* * * *}$ \\
\hline AGE & $0.068^{* * *}$ & -0.000 & $0.086^{* * *}$ & -0.008 & 1.000 & $0.386^{* * *}$ & 0.011 & $0.089^{* * * *}$ & $-0.133^{* * *}$ & 0.015 & $0.043^{* * * *}$ & $-0.051^{* * *}$ & $0.115^{* * *}$ \\
\hline TENURE & $-0.043^{* * *}$ & $0.039^{* * * *}$ & $0.041^{* * *}$ & $-0.032^{* * *}$ & $0.378^{* * *}$ & 1.000 & -0.002 & $0.025^{* * *}$ & 0.005 & $-0.191^{* * *}$ & $0.036^{* * *}$ & $0.096^{* * *}$ & $0.050^{* * * *}$ \\
\hline MBA & $0.118^{* * * *}$ & $-0.063^{* * *}$ & $0.071^{* * * *}$ & $0.102^{* * *}$ & $0.020^{* *}$ & -0.006 & 1.000 & $0.031^{* * *}$ & $-0.077^{* * * *}$ & $0.019^{* *}$ & $-0.132^{* * *}$ & -0.014 & $0.060^{* * *}$ \\
\hline GENDER & $-0.016^{*}$ & 0.007 & $-0.085^{* * *}$ & 0.012 & $0.081^{* * *}$ & $0.028^{* * *}$ & $0.031^{* * *}$ & 1.000 & $-0.097^{* * *}$ & $0.016^{*}$ & $0.036^{* * *}$ & $-0.023^{* *}$ & $0.092^{* * * *}$ \\
\hline CASH & $-0.186^{* * *}$ & $0.047^{* * * *}$ & $-0.033^{* * *}$ & $-0.088^{* * * *}$ & $-0.151^{* * *}$ & $0.078^{* * *}$ & $-0.096^{* * *}$ & $-0.099^{* * * *}$ & 1.000 & $-0.039^{* * *}$ & $-0.319^{* * * *}$ & $0.101^{* * *}$ & $-0.556^{* * *}$ \\
\hline CEO_CHG & 0.006 & 0.011 & $-0.040^{* * * *}$ & $0.015^{*}$ & 0.006 & $-0.272^{* * *}$ & $0.019^{* *}$ & $0.016^{*}$ & $-0.046^{* * * *}$ & 1.000 & 0.003 & $-0.057^{* * * *}$ & -0.008 \\
\hline $\mathrm{BM}$ & $-0.354^{* * *}$ & $-0.070^{* * * *}$ & -0.006 & $-0.039^{* * *}$ & $0.037^{* * * *}$ & $0.033^{* * *}$ & $-0.094^{* * *}$ & 0.007 & $-0.244^{* * *}$ & 0.009 & 1.000 & $-0.170^{* * *}$ & $0.193^{* * * *}$ \\
\hline SGR & $0.027^{* * *}$ & $-0.020^{* * *}$ & $-0.060^{* * *}$ & -0.007 & $-0.061^{* * * *}$ & $0.063^{* * * *}$ & 0.005 & $-0.026^{* * *}$ & $0.087^{* * * *}$ & $-0.046^{* * *}$ & $-0.117^{* * * *}$ & 1.000 & $-0.113^{* * * *}$ \\
\hline LEVERAGE & $0.220^{* * * *}$ & $0.086^{* * *}$ & $0.035^{* * * *}$ & $0.036^{* * *}$ & $0.128^{* * *}$ & $0.050^{* * * *}$ & $0.060^{* * *}$ & $0.088^{* * *}$ & $-0.453^{* * *}$ & -0.013 & $0.188^{* * * *}$ & $-0.073^{* * *}$ & 1.000 \\
\hline
\end{tabular}

${ }^{*},{ }^{* *}$ and ${ }^{* * *}$ mean statistical significance at $10 \%, 5 \%$, and $1 \%$ respectively. 
Table 4 examines the influence of general managerial ability on firm performance and risk. ROE multiplied by 100 is the proxy of performance. CEO age and tenure are expressed as the natural logarithm of the variable. MBA is a dummy variable that equals one if the $\mathrm{CEO}$ has a master of business administration degree, and zero, otherwise. Gender is a dummy variable that equals one if the CEO is a male and zero, otherwise. CEO CHG is a dummy variable that takes a value one if the firm changed CEO, and zero, otherwise. We examine the effect of the General Ability Index on Return on Equity (ROE) and stdROE. We find evidence that the CEO's ability is not significant with firm performance.

Table 4: Firm performance, risk and general managerial ability

\begin{tabular}{|c|c|c|}
\hline & ROE & stdROE \\
\hline \multirow[t]{2}{*}{ Intercept } & 14.289 & 10.381 \\
\hline & $(1.62)$ & $(0.97)$ \\
\hline \multirow[t]{2}{*}{ GAI } & 0.300 & $1.060^{* * *}$ \\
\hline & $(1.48)$ & (3.39) \\
\hline \multirow[t]{2}{*}{ strategy } & $-0.614^{* * *}$ & 0.117 \\
\hline & $(-6.45)$ & $(1.03)$ \\
\hline \multirow[t]{2}{*}{ age } & $10.760^{* * *}$ & $-6.537^{* *}$ \\
\hline & $(5.78)$ & $(-2.30)$ \\
\hline \multirow[t]{2}{*}{ tenure } & $-1.108^{* * *}$ & $1.453^{* * *}$ \\
\hline & $(-4.47)$ & $(3.62)$ \\
\hline \multirow[t]{2}{*}{ MBA } & $2.209^{* * *}$ & $-3.142^{* * *}$ \\
\hline & $(4.85)$ & $(-4.46)$ \\
\hline \multirow[t]{2}{*}{ gender } & $-4.854^{* *}$ & 1.848 \\
\hline & $(-2.56)$ & $(1.38)$ \\
\hline \multirow[t]{2}{*}{ cash } & $-27.843^{* * *}$ & $10.800^{* * *}$ \\
\hline & $(-13.74)$ & $(4.28)$ \\
\hline \multirow[t]{2}{*}{ CEO_CHG } & -0.201 & $2.122^{*}$ \\
\hline & $(-0.27)$ & $(1.75)$ \\
\hline \multirow[t]{2}{*}{$\mathrm{BM}$} & $-45.137^{* * *}$ & $-7.112^{* * *}$ \\
\hline & $(-38.75)$ & $(-4.06)$ \\
\hline \multirow[t]{2}{*}{ SGR } & $3.404^{* * *}$ & -2.149 \\
\hline & $(2.60)$ & $(-1.34)$ \\
\hline \multirow[t]{2}{*}{ leverage } & $44.670^{* * *}$ & $23.791^{* * *}$ \\
\hline & $(16.24)$ & $(7.28)$ \\
\hline Year & YES & YES \\
\hline Industry & YES & YES \\
\hline $\operatorname{Adj~} R^{2}$ & $33.80 \%$ & $6.71 \%$ \\
\hline $\mathrm{N}$ & 11642 & 4755 \\
\hline
\end{tabular}

The t-statistics are reported in parentheses.
This finding supports Custódio et al. (2013) theory that there is a statistically insignificant relation between firm performance and the index of the general managerial ability of the CEO. We also find that generalists involve more risks than specialists do. Generalist CEOs could be particularly important at the time of shocks to the firm and they might be hired to perform difficult tasks such as restructuring and acquisitions so that firms face a higher risk.

Table 5 shows the relation between general managerial ability coupled with strategy misfit and firm performance or risk by testing general managerial ability and its interaction with the strategy on firm performance and risk. When generalists work for prospectors, the firm performance is much better, but there are some risks for them. However, prospectors are much better at adapting to risk and uncertainty (Higgins et al., 2015). When specialists work for defenders, the firm performance is much better. Prospectors are innovative companies seeking to identify and exploit new product and market opportunities (Miles \& Snow, 1978, 2003). This requires prospectors to develop multiple technologies for a diverse product mix. Technological flexibility means there are a lot of changes in management (Bentley et al., 2013). Thus, they need CEOs with rich managerial ability (i.e., Generalist CEOs). Defenders focus on efficiency in the production and distribution of goods and services (Miles \& Snow, 1978, 2003). They just develop related products and services rather than pursuing new products and market opportunities (Bentley et al., 2013). Therefore, they need CEOs who are specialized in some aspect (i.e., Specialist CEOs).

One of the reasons why the relationship between managerial ability and firm performance is different is the strategy that different firms follow. The managerial ability will affect performance positively only if it is congruent with a firm chosen strategy.

Another possible reason is that under different conditions, the relationship between managerial ability and firm performance may be different. Miles and Snow $(1978,2003)$ suggest that because prospectors grow through product and market development, their growth may occur in spurts. Unlike prospectors, defenders grow cautiously and incrementally through market penetration and hence demonstrate low steady growth. We conclude that business strategy is related to growth opportunity, so we examine the relationship between managerial ability and firm performance or risk with different growth opportunities in the next section.

Custódio et al. (2013) found that the effect of general managerial ability is pervasive across firms with different corporate governance mechanisms. Mitra, Jaggi, and AlHayale (2019) suggest that overconfident firms with higher managerial ability pay lower audit fees. To investigate 
whether corporate governance and CEO overconfidence may have an influence on general managerial ability, we control for them, respectively, in the next section.

Table 5: General managerial ability and firm performance and risk

\begin{tabular}{|c|c|c|}
\hline & ROE & stdROE \\
\hline \multirow[t]{2}{*}{ Intercept } & $21.248^{* *}$ & 17.083 \\
\hline & $(2.35)$ & $(1.52)$ \\
\hline \multirow[t]{2}{*}{ GAI } & $-3.302^{* *}$ & -2.513 \\
\hline & $(-2.28)$ & $(-1.29)$ \\
\hline \multirow[t]{2}{*}{ GAI*strategy } & $0.191^{* *}$ & $0.189^{*}$ \\
\hline & $(2.46)$ & $(1.72)$ \\
\hline \multirow[t]{2}{*}{ strategy } & $-1.013^{* * *}$ & -0.252 \\
\hline & $(-5.31)$ & $(-1.15)$ \\
\hline \multirow[t]{2}{*}{ age } & $10.878^{* * *}$ & $-6.491^{* *}$ \\
\hline & $(5.84)$ & $(-2.29)$ \\
\hline \multirow[t]{2}{*}{ tenure } & $-1.103^{* * *}$ & $1.474^{* * *}$ \\
\hline & $(-4.45)$ & $(3.70)$ \\
\hline \multirow[t]{2}{*}{ MBA } & $2.205^{* * *}$ & $-3.121^{* * *}$ \\
\hline & $(4.84)$ & $(-4.44)$ \\
\hline \multirow[t]{2}{*}{ gender } & $-4.951^{* * *}$ & 1.880 \\
\hline & $(-2.61)$ & $(1.41)$ \\
\hline \multirow[t]{2}{*}{ cash } & $-28.019^{* * *}$ & $10.734^{* * *}$ \\
\hline & $(-13.81)$ & $(4.26)$ \\
\hline \multirow[t]{2}{*}{ CEO_CHG } & -0.181 & $2.161^{*}$ \\
\hline & $(-0.25)$ & $(1.78)$ \\
\hline \multirow[t]{2}{*}{$\mathrm{BM}$} & $-45.083^{* * *}$ & $-7.054^{* * *}$ \\
\hline & $(-38.87)$ & $(-4.04)$ \\
\hline \multirow[t]{2}{*}{ SGR } & $3.383^{* * *}$ & -2.135 \\
\hline & $(2.58)$ & $(-1.33)$ \\
\hline \multirow[t]{2}{*}{ leverage } & $44.677^{* * *}$ & $23.771^{* * *}$ \\
\hline & $(16.24)$ & $(7.29)$ \\
\hline Year & YES & YES \\
\hline Industry & YES & YES \\
\hline $\operatorname{Adj} R^{2}$ & $33.84 \%$ & $6.76 \%$ \\
\hline $\mathrm{N}$ & 11642 & 4755 \\
\hline
\end{tabular}

\section{Robustness Tests}

Following Bentley et al. (2013), we control for a growth opportunity to investigate whether growth opportunity would influence business strategy. In Table 6, we investigate the relation between general managerial ability and strategy misfit and firm performance and risk with different growth opportunities, which are measured by Tobin's Q. In our sample, most companies are with Tobin's
Q higher than 1, so we include the companies with Tobin's $\mathrm{Q}$ higher than its median in our test. We find that general managerial ability and strategy misfit affects firm performance and risk. When generalists work for prospectors, the firm performance is much better. When specialists work for defenders, the firm performance is much better. That means in firms with higher growth opportunities, when they recruit CEOs, they need to consider their chosen strategy to increase their firm performance. Thus, our results suggest that business strategy is not a proxy for growth opportunity.

Table 6: Sensitivity analysis for those firms with better growth opportunities

\begin{tabular}{|c|c|c|}
\hline & ROE & stdROE \\
\hline \multirow[t]{2}{*}{ Intercept } & $33.509^{* *}$ & $61.118^{* * *}$ \\
\hline & $(2.39)$ & $(3.29)$ \\
\hline \multirow[t]{2}{*}{ GAI } & $-5.318^{* *}$ & -3.486 \\
\hline & $(-2.18)$ & $(-1.23)$ \\
\hline \multirow[t]{2}{*}{ GAI*strategy } & $0.294^{* *}$ & 0.240 \\
\hline & $(2.29)$ & $(1.54)$ \\
\hline \multirow[t]{2}{*}{ strategy } & $-1.298^{* * *}$ & -0.309 \\
\hline & $(-3.78)$ & $(-1.06)$ \\
\hline \multirow[t]{2}{*}{ age } & $14.591^{* * *}$ & $-15.127^{* * *}$ \\
\hline & $(5.30)$ & $(-3.23)$ \\
\hline \multirow[t]{2}{*}{ tenure } & $-0.849^{* *}$ & $1.955^{* * *}$ \\
\hline & $(-2.18)$ & $(3.58)$ \\
\hline \multirow[t]{2}{*}{ MBA } & 0.759 & $-4.047^{* * *}$ \\
\hline & $(1.16)$ & $(-3.89)$ \\
\hline \multirow[t]{2}{*}{ gender } & -4.351 & $3.936^{* *}$ \\
\hline & $(-1.56)$ & (1.99) \\
\hline \multirow[t]{2}{*}{ cash } & $-34.522^{* * *}$ & $7.380^{* *}$ \\
\hline & $(-11.89)$ & $(2.45)$ \\
\hline \multirow[t]{2}{*}{ CEO_CHG } & $-2.046^{*}$ & 0.506 \\
\hline & $(-1.91)$ & $(0.36)$ \\
\hline \multirow[t]{2}{*}{$\mathrm{BM}$} & $-128.249^{* * *}$ & $-24.111^{* * *}$ \\
\hline & $(-27.99)$ & $(-4.37)$ \\
\hline \multirow[t]{2}{*}{ SGR } & $-7.183^{* * *}$ & -2.385 \\
\hline & $(-2.98)$ & $(-1.15)$ \\
\hline \multirow[t]{2}{*}{ leverage } & $44.693^{* * *}$ & $24.402^{* * *}$ \\
\hline & $(10.84)$ & $(4.90)$ \\
\hline Year & YES & YES \\
\hline Industry & YES & YES \\
\hline Adj $R^{2}$ & $42.68 \%$ & $9.02 \%$ \\
\hline $\mathrm{N}$ & 5824 & 2494 \\
\hline
\end{tabular}

${ }^{*},{ }^{* *}$ and ${ }^{* * *}$ mean statistical significance at $10 \%, 5 \%$, and $1 \%$ respectively. The t-statistics are reported in parentheses. 
Table 7: Sensitivity analysis by corporate governance index

\begin{tabular}{|c|c|c|}
\hline \multicolumn{3}{|c|}{ Panel A: GIM index in Top $50 \%$} \\
\hline & ROE & stdROE \\
\hline \multirow[t]{2}{*}{ Intercept } & 9.672 & 9.260 \\
\hline & $(0.70)$ & $(0.63)$ \\
\hline \multirow[t]{2}{*}{ GAI } & $-3.786^{*}$ & -3.836 \\
\hline & $(-1.86)$ & $(-1.46)$ \\
\hline \multirow[t]{2}{*}{ GAI*strategy } & $0.259^{* *}$ & $0.271^{*}$ \\
\hline & $(2.29)$ & $(1.92)$ \\
\hline \multirow[t]{2}{*}{ strategy } & $-0.825^{* * *}$ & $-0.746^{* *}$ \\
\hline & $(-3.77)$ & $(-2.54)$ \\
\hline \multirow[t]{2}{*}{ age } & $12.141^{* * *}$ & -0.593 \\
\hline & $(4.26)$ & $(-0.17)$ \\
\hline \multirow[t]{2}{*}{ tenure } & $-1.023^{* * *}$ & 0.332 \\
\hline & $(-2.68)$ & $(0.66)$ \\
\hline \multirow[t]{2}{*}{ MBA } & $2.873^{* * *}$ & -1.657 \\
\hline & $(4.53)$ & $(-1.63)$ \\
\hline \multirow[t]{2}{*}{ gender } & $-8.832^{* * *}$ & 1.917 \\
\hline & $(-2.18)$ & $(1.08)$ \\
\hline \multirow[t]{2}{*}{ cash } & $-23.617^{* * *}$ & $8.695^{*}$ \\
\hline & $(-8.05)$ & $(1.84)$ \\
\hline \multirow[t]{2}{*}{ CEO_CHG } & 0.536 & 2.199 \\
\hline & $(0.52)$ & $(1.34)$ \\
\hline \multirow[t]{2}{*}{$\mathrm{BM}$} & $-42.641^{* * *}$ & $-10.205^{* * *}$ \\
\hline & $(-27.50)$ & $(-3.31)$ \\
\hline \multirow[t]{2}{*}{ SGR } & $6.932^{* * *}$ & -2.904 \\
\hline & $(4.01)$ & $(-1.45)$ \\
\hline \multirow[t]{2}{*}{ leverage } & $46.494^{* * *}$ & $31.178^{* * *}$ \\
\hline & $(10.95)$ & $(5.73)$ \\
\hline Year & YES & YES \\
\hline Industry & YES & YES \\
\hline $\operatorname{Adj} R^{2}$ & $34.65 \%$ & $12.25 \%$ \\
\hline $\mathrm{N}$ & 5924 & 2455 \\
\hline \multicolumn{3}{|c|}{ Panel B: GIM index in Bottom 50\% } \\
\hline & ROE & stdROE \\
\hline \multirow[t]{2}{*}{ Intercept } & $29.554 * *$ & 4.903 \\
\hline & $(2.50)$ & $(0.25)$ \\
\hline \multirow[t]{2}{*}{ GAI } & -2.615 & 0.063 \\
\hline & $(-1.35)$ & $(0.02)$ \\
\hline \multirow[t]{2}{*}{ GAI*strategy } & 0.107 & 0.017 \\
\hline & $(1.06)$ & $(0.11)$ \\
\hline \multirow[t]{2}{*}{ strategy } & $-1.192 * * *$ & 0.441 \\
\hline & $(-3.81)$ & $(1.26)$ \\
\hline Control Variables & YES & YES \\
\hline Year & YES & YES \\
\hline Industry & YES & YES \\
\hline $\operatorname{Adj~} R^{2}$ & $37.06 \%$ & $6.55 \%$ \\
\hline $\mathrm{N}$ & 5718 & 2300 \\
\hline
\end{tabular}

Table 7 depicts how the quality of a firm's corporate governance affects the general ability and its interaction with the strategy on firm performance and risk. We classify our sample as high and low corporate governance groups by the median of the GIM index (Gompers, Ishii, \& Metrick, 2003). The firms in Panel A with inferior corporate governance, general managerial ability, and strategy misfit affect firm performance and risk. When generalists work for prospectors, the firm performance is much better, but there are some risks for them. When specialists work for defenders, the firm performance is much better. However, the firms with superior corporate governance in Panel B, we find a statistically insignificant relation with firm performance, risk, general managerial ability, and strategy misfit. That means that firms with superior corporate governance, when they recruit CEOs, need to consider their chosen strategy to increase their firm performance.

Table 8 reports the relation between general managerial ability coupled with strategy misfit and firm performance or risk with different overconfident CEOs. Following Malmendier and Tate (2005), we measure CEOs' overconfidence as their stock options are more than 67 percent in the money if they hold options at least twice during the sample period. We find that general managerial ability and strategy misfit affects firm performance and risk. When generalists work for prospectors, the firm performance is much better. When specialists work for defenders, the firm performance is much better. However, there are some risks for both of them due to overconfidence. Although CEOs are overconfident, the fit between the chosen strategy and general managerial ability is positively associated with firm performance.

Table 8: Sensitivity analysis for those firms with overconfident CEO

\begin{tabular}{|c|c|c|}
\hline & ROE & stdROE \\
\hline Intercept & $57.262^{* *}$ & 14.065 \\
\hline & $(2.28)$ & $(0.80)$ \\
\hline GAI & $-5.381^{* *}$ & $-7.308^{* *}$ \\
\hline & $(-2.35)$ & $(-2.37)$ \\
\hline GAI*strategy & $0.321^{* *}$ & $0.416^{* *}$ \\
\hline & $(2.53)$ & $(2.46)$ \\
\hline strategy & $-1.439^{* * *}$ & $-0.914^{* *}$ \\
\hline & $(-5.17)$ & $(-2.22)$ \\
\hline age & 4.293 & -0.079 \\
\hline & $(1.27)$ & $(-0.02)$ \\
\hline tenure & $-1.155^{* *}$ & 0.926 \\
\hline & $(-2.48)$ & $(1.26)$ \\
\hline MBA & 0.696 & $-3.686^{* * *}$ \\
\hline
\end{tabular}




\begin{tabular}{|c|c|c|}
\hline & ROE & stdROE \\
\hline & $(0.79)$ & $(-2.97)$ \\
\hline \multirow[t]{2}{*}{ gender } & -0.696 & -3.030 \\
\hline & $(-0.33)$ & $(-1.49)$ \\
\hline \multirow[t]{2}{*}{$\mathrm{CASH}$} & $-25.493^{* * *}$ & 1.797 \\
\hline & $(-6.93)$ & $(0.38)$ \\
\hline \multirow[t]{2}{*}{ CEO_CHG } & $-3.479^{* *}$ & 0.544 \\
\hline & $(-2.45)$ & $(0.28)$ \\
\hline \multirow[t]{2}{*}{$\mathrm{BM}$} & $-42.921^{* * *}$ & $-12.203^{* * * *}$ \\
\hline & $(-18.81)$ & $(-4.08)$ \\
\hline \multirow[t]{2}{*}{ SGR } & $5.568^{* *}$ & -2.946 \\
\hline & $(2.41)$ & $(-1.18)$ \\
\hline \multirow[t]{2}{*}{ Leverage } & $39.533^{* * *}$ & $25.094^{* * *}$ \\
\hline & $(7.45)$ & $(3.84)$ \\
\hline Year & YES & YES \\
\hline Industry & YES & YES \\
\hline Adj $R^{2}$ & $32.22 \%$ & $7.72 \%$ \\
\hline $\mathrm{N}$ & 3259 & 1461 \\
\hline
\end{tabular}

\section{Discussion and Conclusion}

Fit in organizational contingency theory has a long tradition (Donaldson, 2001). Misfit is defined as a condition that leads to diminished performance; yet, it is less well developed in terms of operational statements and empirical tests. In this paper, we extend fit relations to develop

In this study, we investigate the impact of general managerial ability on firm performance and risk. Furthermore, we examine the impact of strategy and general managerial ability fit on firm performance and risk. As predicted, we find that generalist CEOs are more suitable for prospectors than specialist CEOs. The result suggests that firms need to consider their chosen business strategy to recruit and select CEOs.

Furthermore, we predict and find that the misfit between business strategy and general managerial ability has a detrimental effect on firm performance and risk. Rather, firms need to align CEO managerial ability to their strategy because the fit between strategy and general managerial ability will affect performance positively.

The results of this study, however, should be interpreted in the light of two limitations. First, this study uses data from US firms. Further research is required to determine whether the results reported here can be extended to other countries. Second, in this study, although we rely on
Bentley et al.'s (2013) STRATEGY measure, we assess business strategy with noise. That measurement error could lead to misclassifying some firms' business strategy. Future research might consider a different approach in classifying a firm's competitive strategy, for example, via surveys.

\section{References}

Andreou, P. C., Ehrlich, D., Karasamani, I., \& Louca, C. (2017). The Impact of Managerial Ability on Crisis-period Corporate Investment. Journal of Business Research, 79, 107-122.

Bentley, K. A., Sharp, N. Y., \& Omer, T. C. (2013). Business Strategy, Financial Reporting Irregularities, and Audit Effort. Contemporary Accounting Research, 30(2), 780-817.

Brockman, P., Lee, H. S., \& Salas, J. M. (2016). Determinants of CEO Compensation: Generalist-specialist versus Insideroutsider Attributes. Journal of Corporate Finance, 39, 53-77.

Cha, S., Hwang, S., \& Kim, Y. (2019). Business Strategy and Overvaluation: Evidence from Korea. Journal of Asian Finance, Economics and Business, 6(4), 83-90. https://doi.org/10.13106/jafeb.2019.vol6.no4.83

Chen, Y., \& Jermias, J. (2014). Business Strategy, Executive Compensation and Firm Performance. Accounting and Finance, 54(1), 113-134.

Choi, W., Han, S., Jung, S. H., \& Kang, T. (2015). CEO's Operating Ability and the Association between Accruals and Future Cash Flows. Journal of Business Finance \& Accounting, 42(5-6), 619-634.

Cunat, V., \& Guadalupe, M. (2009). Globalization and the Provision of Incentives inside the Firm: the Effect of Foreign Competition. Journal of Labor Economics, 27(2), 179-212.

Custódio, C., Ferreira, M., \& Matos, P. (2013). Generalists versus Specialists: Lifetime Work Experience and Chief Executive Officer Pay. Journal of Financial Economics, 108, 471-492.

Custódio, C., Ferreira, M., \& Matos, P. (2019). Do General Managerial Skills Spur Innovation? Management Science, 65(2), 459-476.

Demerjian, P., Lev, B., \& McVay, S. (2012). Quantifying Managerial Ability: A New Measure and Validity Tests. Management Science, 58(7), 1229-1248.

Dent, J. F. (1990). Strategy, Organization and Control: Some Possibilities for Accounting Research. Accounting, Organizations and Society, 15(1-2), 3-25.

Donaldson, L. (2001). The Contingency Theory of Organizations. Thousand Oaks, CA: Sage Publications.

Gabaix, X., \& Landier, A. (2008). Why Has CEO Pay Increased So Much? The Quarterly Journal of Economics, 123(1), 49100 .

Garicano, L., \& Rossi-Hansberg, E. (2006). Organization and Inequality in a Knowledge Economy. The Quarterly Journal of Economics, 121(4), 1383-1435.

Gompers, P., Ishii, J., \& Metrick, A., (2003). Corporate governance and equity prices. The Quarterly Journal of Economics, 118(1), 107-155.

Gounopoulos, D., \& Pham, H. (2018). Specialist CEOs and IPO survival. Journal of Corporate Finance, 48, 217-243.

Govindarajan, V., \& Shank, J. (1993). Strategic Cost 
Management: The New Tool for Competitive Advantage. New York, NY: The Free Press.

Graham, J., Harvey, C., \& Puri, M. (2010). Managerial attitudes and corporate actions (Working paper). Duke University.

Habib, A., \& Hasan, M. M. (2016). Business Strategy, Overvalued Equities, and Stock Price Crash Risk. Research in International Business and Finance, 39, 389-405.

Hambrick, D. C. (1981). Environment, Strategy, and Power Within Top Management Teams. Administrative Science Quarterly, 26(2), 253-275.

Hambrick, D. C. (1983). Some Tests of the Effectiveness and Functional Attributes of Miles and Snow's strategic types. The Academy of Management Journal, 26(1), 5-26.

Higgins, D., Omer, T. C., \& Phillips, J. D. (2015). The Influence of a Firm's Business Strategy on its Tax Aggressiveness. Contemporary Accounting Research, 32(2), 674-702.

Hubbard, R., \& Palia, D. (1995). Executive Pay and Performance: Evidence from the US Banking Industry. Journal of Financial Economics, 39(1), 105-130.

Ittner, C. D., Larcker, D. F., \& Rajan, M. V. (1997). The Choice of Performance Measures in Annual Bonus Contracts. The Accounting Review, 72(2), 231-255.

Langfield-Smith, K. (1997). Management Control Systems and Strategy: A Critical Review. Accounting, Organizations and Society, 22(2), 207-232.

Leverty, J. T., \& Grace, M. F. (2012). Dupes or Incompetents? An Examination of Management's Impact on Firm Distress. The Journal of Risk and Insurance, 79(3), 751-783.

Liu, Z. N., \& Zhang, X. Z. (2017). The Business Strategy, Ownership and Risk-taking. Paper presented at the 9th International Conference on Financial Risk and Corporate Finance Management, Takamatsu City, Japan, July 1-3, 2017.

Malmendier, U., \& G. Tate. (2005). CEO overconfidence and corporate investment. The Journal of Finance, 60(6), 26612700 .

March, J. G. (1991). Exploration and Exploitation in Organizational Learning. Organization Science, 2(1), 71-87.

Mark, M. K., Morten, S., \& Steven, N. K. (2012). Which CEO Characteristics and Abilities Matter? The Journal of Finance, 67(3), 973-1007.

May, D. (1995). Do Managerial Motives Influence Firm Risk Reduction Strategies? The Journal of Finance, 50(4), 12911308.

Miles, R. E., \& Snow, C. C. (1978). Organizational Strategy, Structure and Process. New York, NY: McGraw-Hill.

Miles, R. E., \& Snow, C. C. (2003). Organizational Strategy, Structure and Process. Stanford, CA: Stanford University Press.

Mintzberg, H. T. (1979). The Structuring of Organizations. Englewood Cliffs, NJ: Prentice-Hall.

Mishra, D. R. (2014). The Dark Side of CEO ability: CEO General Managerial Skills and Cost of Equity Capital. Journal of Corporate Finance, 29, 390-409.

Mitra, S., Jaggi, B., \& Al-Hayale, T. (2019). Managerial overconfidence, ability, firm-governance and audit fees. Review of Quantitative Finance and Accounting, 52(3), 841-870.

Mukherjee, T., \& Nguyen, H. (2018). CEO Ability and Firm Performance: Stock Market and Job Market Reactions. Journal of Economics and Finance, 42(1), 138-154.

Murphy, K. J., \& Zabojnik, J. (2004). CEO Pay and Appointments: a Market-based Explanation for Recent Trends. The American Economic Review, 94(2), 192-196.

Nguyen, H. M., Mai, L. T., \& Huynh, T. L. (2019). The Role of Transformational Leadership toward Work Performance through Intrinsic Motivation: A Study in the Pharmaceutical Field in Vietnam. Journal of Asian Finance, Economics and Business, 6(4), 201-212. https://doi.org/10.13106/jafeb.2019.vol6.no4.201

Porter, M. E. (1980). Competitive strategy: Techniques for Analyzing Industries and Competitors. New York, NY: The Free Press.

Rajagopalan, N. (1997). Strategic Orientations, Incentive Plan Adoptions, and Firm Performance: Evidence from Electric Utility Firms. Strategic Management Journal, 18(10), 761785.

Ramaswamy, K., \& Thomas, A.S. (1996). Matching Managers to Strategy: Further Tests of the Miles and Snow Typology. British Journal of Management, 7(3), 247-261.

Rosen, S. (1981). The Economics of Superstars. The American Economic Review, 71(5), 845-858.

Seifzadeh, P. (2011). Business Strategy and the Synergistic Combination of Exploration and Exploitation (Working paper). University of Western Ontario.

Sheikh, M. F., Bhutta, A. I., \& Sultan, J. (2019). CEO Compensation and Unobserved Firm Performance in Pakistan. Journal of Asian Finance, Economics and Business, 6(3), 305-313. https://doi.org/10.13106/jafeb.2019.vol6.no3.305

Simons. R. (1987). Accounting Control Systems and Business Strategy: An Empirical Analysis. Accounting, Organizations and Society, 12(4), 357-374.

Treacy, M., \& Wiersema, F. (1995). The Discipline of Market Leaders. Reading, MA: Addison-Wesley.

Waterhouse, J., \& Svendsen. A. (1998). Strategic Performance Monitoring and Management: Using Non-financial Measures to Improve Corporate Governance. Toronto, Canada: The Canadian Institute of Chartered Accountants.

Xuan, Y. (2009). Empire-Building or Bridge-Building? Evidence from New CEOs' Internal Capital Allocation Decisions. The Review of Financial Studies, 22(12), 4919-4948.

Yung, K., \& Chen, C. (2018). Managerial ability and firm risktaking behavior. Review of Quantitative Finance and Accounting, 51(4), 1005-1032. 